IRA-International Journal of Management \&

Social Sciences

ISSN 2455-2267; Vol.16, Issue 03 (July-Sep. 2020)

Pg. no. 68-78.

Institute of Research Advances

http://research-advances.org/index.php/RAJMSS

\title{
A Survey Analysis on TV Viewers: Unethical Issues in Telugu Drama Serials
}

\author{
Dr. J. Madhu Babu" ${ }^{1 \#}$, K. M. M. Krishna ${ }^{2}$ \\ Assistant Professor, Journalism and Mass Communication, Acharya Nagarjuna University, India. \\ Research Scholar, Journalism and Mass Communication, Acharya Nagarjuna University, India. \\ \# corresponding author. \\ Type of Work: Peer Reviewed. \\ DOl: http://dx.doi.org/10.21013/jmss.v16.n3.p1 \\ How to cite this paper: \\ Babu, J.M., Krishna, K.M.M. (2020). A Survey Analysis on TV Viewers: Unethical Issues in Telugu \\ Drama Serials. IRA-International Journal of Management \& Social Sciences (ISSN 2455-2267), 16(3), \\ 68-78. doi:http://dx.doi.org/10.21013/jmss.v16.n3.p1
}

(C) Institute of Research Advances.

(cc) EY-NC

This work is licensed under a Creative Commons Attribution-Non Commercial 4.0 International License subject to a proper citation to the publication source of the work.

Disclaimer: The scholarly papers as reviewed and published by the Institute of Research Advances (IRA) are the views and opinions of their respective authors and are not the views or opinions of the IRA. The IRA disclaims of any harm or loss caused due to the published content to any party.

Institute of Research Advances is an institutional publisher member of Publishers International Linking Association Inc. (PILA-CrossRef), USA. The institute is an institutional signatory to the Budapest Open Access Initiative, Hungary advocating the open-access of scientific and scholarly knowledge. The Institute is a registered content provider under Open Access Initiative Protocol for Metadata Harvesting (OAI-PMH).

The journal is indexed \& included in WorldCat Discovery Service (USA), CrossRef Metadata Search (USA), WorldCat (USA), OCLC (USA), Open J-Gate (India), EZB (Germany) Scilit (Switzerland), Airiti (China), Bielefeld Academic Search Engine (BASE) of Bielefeld University, Germany, PKP Index of Simon Fraser University, Canada. 


\section{ABSTRACT}

Television in India has proven a most influential infotainment media powerful and popular among its audience. Television plays a vital role in the telecast entertaining program. Fiction has been a popular genre on Indian Television. A common habit among most of the Indian families is watching drama serials in the evening as one of the best time-pass activities i.e. why serials have become part and parcel of most of its viewer's lives. TV drama serials have become one of the most popular offerings. It affects people irrespective of gender, age, and other demographic variables. The study was conducted to throw light towards various Television viewing habits among the Telugu audience. A sample of 316 respondents from Amravati the new capital of the newly formed state of Andhra Pradesh was selected for survey analysis. Structured questioners were distributed to them and the responses were collected. A Chi-square test is used to analyze the collected data. The study also highlighted the opinions of viewers on Telugu drama serials. Focused group discussions have been conducted.

\section{Introduction}

Keywords: Telugu TV channels, drama serials, viewing habits.

Indian Television began its journey in 1959 and with the launch of Satellite Instructional Television Experiment (SITE) 1975-76 in India the separation of radio and television in 1976 and color TV transmission started in 1986. India's first soap opera Hum Log (we the people) which first aired on 7 July 1984 and concluded with 154 episodes was the longest-running serials in the history of Indian Television at the time it ended. It had an audience of 60 million. It was written by Manohar Shyam Joshi and directed by Vasudev Kumar. It was run for over 17 months. Opera is the literary products of the electronic media. They are simply literature to be seen and not to be read. Soap operas are radio or television serials dealing especially with domestic situations and frequently characterized by melodrama and sentimentality. The term soap opera originated from radio dramas being sponsored by soap manufacturers. It dealt with pro-social issues like the betterment of women's status family harmony, family planning, national integration, maintenance of traditional culture, problems urban life, dowry, alcoholism (Aravind Singhal\& Everett M.Rogers 1988). Joshi went on to write other hit shows such as Buniyaad (1987) and Kakaji Kahin (1988). Later, other serials, like Khandaan, Shanti; mythological serials Ramayana(1987), Mahabharath(1988-89), religious serials such as Jai Hanuman, Sri Krishna, Om Namhashivay; biographical serials The sword of Tippu Sulthan; fantasy serials like Shaktimaan attracted a large audience.

After economic liberalization, the Indian Television audiences were ready for something new, having already been primed by American soap. In 2000 Balaji Telefilms one of India's pioneer Television company, stepped in to fill this gap with two hit serials, Kyunki Sas be Kabi Bahu Thi(because of mother in law was also once a daughter in law) and Kahani Ghar Ghar ki (The story of every home) and she producing popular "K" serials such as Kasauti Zindagi Kay, Kutumb, Kahin toh hoga. Ekta Kapoor, the founder of Balaji Telefilms created the storyline with issues like conspiracies, extramarital affairs, sex, murders with gaudy make-up designer dresses high profile home decorations designer jewelry, chunky accessories.

The soap theme sunder went a paradigm shift from the year 2008 on words with social problems like child marriage, female feticide, child labor, bonded labor, and farmers' suicides providing the thematic context to this news bread of soaps.

\section{Telugu soap operas}

The first Telugu sponsored serial broadcasted on DD was Anaganaga Oka Sobha, it was directed by Dharmavarm Subramanyam. Later, DD telecasted a serial on against to dowry system that is Kumkumagni. After that in DD, Manjula Naidu's serial Ruthuragalu was very entertaining. With the advent of private TV, the Gemini Channel opened. The Manjulanadu serials Chakravakam, Mogalirekulu, Agnipoolu, Sravanasameeralu, Keratalu were very popular. Similarly, the Chittemma serial aired by Gemini became very popular. It is a product of Radon headed by the film actress Radhika.

\section{Review of Literature}

There have been a lot of studies done in India and abroad on Television with special reference to its viewers. The studies come up with different perspectives and results in changing media situation. The effect of TV on viewers by Andal Narayanan says that Television everywhere through the globe has implied various things to various individuals. It has been classified as "opium of the masses", "the biggest aspidistra in the world", and so forth. The advent of TV in India has understandably raised intriguing questions on its timeliness, usefulness suitability, potential the promises it holds for the future, and its inherent perils. Its effects on the viewers are kaleidoscopic and this subject has been debatable everywhere (Narayanan1987, Ponsindhu, 2014). 
Shashi Kaul and Shradha Shani (2010) analyses the portrayal of women in television serials. The researchers conducted the study in Jammu on 60 couples, 35 - 50 years of age, who were the regular viewers of television, Chose purposively. They saw that there is a stereotypical portrayal of women, where women are projected as 'house-wives and glamorous'. According to Visakha Dharba (2012), the target audience of Indian television serials are mainly women particularly housewives and elder women. Media is viewed as a central impact bearer of modern society (Aaliya Ahmed and Malik Zahra Khalid, 2012). Soap-operas impact the mindset of the women in two aspects, there thinking level and their attitude, behavior. Vandana (2011), as indicated by the examination "Impact of television on rural women". 47\% of respondents spent 1-2 hours in a day on viewing television. $48 \%$ of respondents like to observe family serials. Shruthi (2014) as indicated by the investigation greater part $(40 \%)$ said that they watch news programs and old movies. Just3\% watch programs with a special thrust on politics. The rest of the numbers (57\%) mostly watch programs such as serials. Devadas \& Ravi (2013) females are more inclined towards certain programs like serials Cookery Shows and health. Anjali Monteiro (1998) reports about increased contents of pre-marital, extra-marital affairs in Indian television programs. At present at least two among the five soap-operas in Hindi as well as regional channels deal with the issue of premarital and extramarital sex. Shoma Munshi's (2009) in her book "Primetime soap operas on Indian television" is the first of its kind to examine prime time soap operas on Indian television. She analysis narrative structure of the soaps in the context of their featured and never-ending timeframes and plot outlines.

Anita Nagulapalli of CMS Media Lab as a team with Padmaja Sha undertook an intensive study of Telugu daily serials to analyze the violence depicted in them. Significantly the data shows i.e. women who predominate as both victims and perpetrators of violence, while men are less contrasted with women even among negative characters.

Drama serials are occupying most of the plots on small screens. The value of serials can be observed in the multiple episode and seasons broadcasted every week. There have been plenty of studies done in India and abroad on television with special reference to its viewers. Pugalendi (2015) researched television program popularity among Chennai urban women and found that the TV viewing habit of homemakers and working women are similar. But the content of the TV programs has a great influence on the minds of women as they are narrow-minded by what they watch. Nidhi Shendurnikar \& Netenda Tamber Tares, in their study, found the women serials are domesticated and she dazzles with culture, family values, possessiveness, and responsibility towards the family. This depiction of women influences the audience to a large extent. Television creates illusions about women with television audiences influenced and unable to distinguish reel won from real.

Many studies have been conducted globally and nationally to study the impact of soap operas on different categories and age groups of the audience. But, limited studies have been conducted on audience opinions on TV channel serials. Particularly there are very few studies done on Telugu soap operas of Andhra Pradesh. The review of the literature presented here starts with the national studies then regional studies on Telugu soap operas. Important studies worth mentioning have been selected to present here.

The Government should interfere in television serials seriously and must appoint a regulatory body to monitor the content (Kaluvoya Anita, 2017). Daily soaps portrayal to which people can relate their lives with. Also, soap operas all around the world are women-centric and have women viewers have a target audience.

\author{
Aim of the study \\ The primary aim of the study is to evaluate the viewer's perception and opinion on Telugu drama serials in \\ Andhra Pradesh.

\section{Research Objectives (RO)} \\ R.O.1.To identify and analyze the demographic profiles of TV viewers in Andhra Pradesh. \\ R.O.2.To examine the viewing habits of viewers. \\ R.O.3.To find out the viewer's priority on serials and channels. \\ R.O.4.To find out the perception of TV viewers on Telugu serials.
}

\title{
Methodology
}

To study the present problem, the researcher has selected the survey method.

\section{Tool of research}

The conventional technique i.e. questionnaire was employed for primary data collection. The questionnaire was originally written in Telugu and translated by self in English. Based on the research objectives, the study combines both quantitative and qualitative methods which include the following. 


\section{Selection of study area}

The study has been conducted a new capital of the newly formed state of Andhra Pradesh. The data was collected from the Velagapudi village of Amravati. Which represents the four important reasons that are economically, politically, and culturally were selected for data collection.

\section{Method of sample}

Simple random sampling was used to collect responses. The data from the 316 questioners were distributed for data collection. In this 244 respondents were watching Telugu serials. The tabulated data depicts the views of respondents relating to information and Television drama serials viewing habits in multi-dimensions.

\section{Variables}

The following research variable has been used in the study. Independent variables; TV channels, serials, age, gender, education, income, occupation, and marital status.

Dependent variable; perception of respondents,

\section{Data collection tools}

Primary data collection; a).field observation b).Questionnaires c). Interview schedules.

Secondary data; the researchers browsed the websites, referred journal reports, and publication for the secondary data.

\section{Statistical techniques used}

To analyze the data the following statistical test used, simple percentage and Chi-square test of association. IBM SPSS Statistics 20 is used for analysis.

\section{Selection of TV channels \\ 1.ETVHD}

ETV is the Telugu TVof the ETV network. It is a network Telugu language news and entertainment satellite Television channels in India. It is based in Hyderabad. Its owner is Romoji Group. It was launched on 27 August 1995. ETV Telugu is a 24x7 satellite channels comprising general enter. All non-Telugu language television channels were acquired by Reliance Industries-owned TV18 in FY 2014-2015 and later rebranded.

\section{Gemini TV HD}

Gemini TV is an Indian pay television channel that was launched on 9 February 1995 by the Sun Network. It is the first-ever Telugu satellite channels. Its HD feed was launched in January 2014. It is a part of Sun Group and is one of Asia's largest TV network. Established on 14 April 1993 by Kalanidhi Maran. The flagship channel is Sun TV. It was the first fully privately owned Tamil channel in India.

\section{STAR Maa}

STAR Maa is an Indian pay Television channel based in Hyderabad the state of Telangana. STAR Maa India its channel is owned by STAR India, a wholly-owned subsidiary of the Walt Disney Company Ltd. Maa Television network was found in 2001. As a corporate entity. While it's main TV channel Maa TV was launched in 2002. The company's second channel Maa music was launched in 2008.

\section{ZEE Telugu}

It is a Telugu cable television channel in India. It is offered by ZEE entertainment enterprises part of the Essel Group. By 2004, the ZEE network had a strong presence in northern, eastern, and western India. Its proposed Telugu language channel marked the network first venture into the southern India entertainment market.ZEE Telugu is the leading Telugu General Entertainment Channel(GEC) from ZEE Entertainment Enterprises Ltd. (ZEEL). Catering a wide variety of content to audiences across goners. ZEE Telugu is the first entertainment in the south market form the ZEE bouquet. It reaches around 75 million people across the country week on week.

\section{DD Saptagiri}

Itis a state-owned television channel telecasting in the Telugu language. The studio was inaugurated on 27 September 2014.

\section{Operational definitions}

1. Soap opera: As a serial drama. Usually dealing with sentimentalized family matters. That is broadcast on television that featured storylines delivery with the lives of multiple characters.

2. Homemaker: A wife who marriages a household while her husband earns the family income. 
3. Divorce: Formal ending of a marriage, permanently separating wife and husband involving the legal process and end of official marriage.

4. Lady villain: A negative female indulges in criminal behavior, evil thoughts, plots evil, and causes discomfiture to others - individuals, family society.

5. Impact: Impact on the cognitive aspects and thinking.

\section{Data analysis}

Table 1.Demographics of Viewers and Non-viewers

\begin{tabular}{|c|c|c|c|c|}
\hline \multicolumn{2}{|c|}{ Demographics } & Total sample & Nonviewers & Viewers \\
\hline \multirow[t]{3}{*}{ Sex } & Male & 160 & 57 & 103 \\
\hline & Female & 156 & 15 & 141 \\
\hline & $\mathrm{X}^{2}=30.37, \mathrm{p}>3.570, \mathrm{df}=1$ & & & \\
\hline \multirow[t]{5}{*}{ Age } & $18-29$ & 99 & 29 & 70 \\
\hline & $30-39$ & 97 & 22 & 75 \\
\hline & $40-49$ & 73 & 9 & 64 \\
\hline & 50 and above99 & 47 & 12 & 35 \\
\hline & $\mathrm{X}^{2}=7.121, \mathrm{p}>0.06811, \mathrm{df}=3$ & & & \\
\hline \multirow[t]{7}{*}{ Education } & Illiterates & 51 & 5 & 46 \\
\hline & Primary & 92 & 14 & 78 \\
\hline & Secondary & 72 & 14 & 58 \\
\hline & Technical & 35 & 12 & 23 \\
\hline & Inter & 57 & 24 & 33 \\
\hline & UG/PG & 9 & 3 & 6 \\
\hline & $X^{2}=23.63, p>0.00025, d f=5$ & & & \\
\hline \multirow{7}{*}{$\begin{array}{l}\text { Income in } \\
\text { Rs. }\end{array}$} & Below 50.000 & 132 & 24 & 108 \\
\hline & 1Lakh & 106 & 16 & 90 \\
\hline & 2Lakh & 48 & 16 & 32 \\
\hline & 3Lakh & 12 & 7 & 5 \\
\hline & 4Lakh & 9 & 5 & 4 \\
\hline & 5Lakh above & 9 & 4 & 5 \\
\hline & $\mathrm{X}^{2}=24.70, \mathrm{p}>0.0001591, \mathrm{df}=5$ & & & \\
\hline \multirow{5}{*}{$\begin{array}{l}\text { Marital } \\
\text { Status }\end{array}$} & Married & 215 & 37 & 178 \\
\hline & Single & 73 & 29 & 44 \\
\hline & Divorce & 10 & 3 & 7 \\
\hline & Widowed & 18 & 3 & 15 \\
\hline & $\mathrm{X}^{2}=16.386, \mathrm{p}>0.0009448, \mathrm{df}=3$ & & & \\
\hline
\end{tabular}

In an attempt to understand the context of an "A Survey Analysis on TV Viewers: Unethical Issues in Telugu Drama Serials". Various genders of respondents were interviewed from age groups, educational levels, occupational status, income groups, and marital status. A questionnaire was administered to 316 respondents in Amravati the findings are as follows.

When the data gathered was analyzed $90.4 \%$ of women respondents were found to watch television serials and the rest of $9.6 \%$ of women said they did not watch television serials, Similarly, $35.6 \%$ of male respondents also said that the did not watch television serials.

Table 2. How many serials watched on an average day with gender?

\begin{tabular}{|l|c|c|c|c|c|c|}
\hline $\begin{array}{l}\text { Number of } \\
\text { Serials }\end{array}$ & Male & $\%$ & Female & $\%$ & Total & $\%$ \\
\hline $1-2$ & 51 & 49.5 & 39 & 27.6 & 90 & 36.9 \\
\hline $3-5$ & 42 & 40.8 & 80 & 56.7 & 122 & 50.0 \\
\hline $6-8$ & 10 & 9.7 & 19 & 13.5 & 29 & 11.9 \\
\hline 9and above & - & - & 3 & 2.12 & 3 & 1.2 \\
\hline Total & 103 & 100.0 & 141 & 100.0 & 244 & 100.0 \\
\hline
\end{tabular}

The study also reveals that $56.6 \%$ of women respondents were found to watching $3-5$ serials, $49.5 \%$ of male respondents were watching 1-2 serials per day. The study sample shows that $13.5 \%$ and $2.12 \%$ of women respondents were watching 6-8 serials and 9 above serials respectively. 
Table 3. How many serials watched on an average day with respondent's age groups?

\begin{tabular}{|l|c|c|c|c|c|}
\hline Age group & 1-2 Serials & $3-5$ Serials & $6-8$ Serials & 9 above Serials & Total \\
\hline $18-29$ & 24 & 38 & 8 & - & 70 \\
\hline $30-39$ & 27 & 37 & 9 & 2 & 75 \\
\hline $40-49$ & 19 & 34 & 10 & 1 & 64 \\
\hline 50 and above & 20 & 13 & 2 & - & 37 \\
\hline Total & 90 & 122 & 29 & 3 & 244 \\
\hline
\end{tabular}

Data presented in table 3 indicate the age-wise respondent's frequency of watching serials per average day. It could be noted that out of the total 244 respondents half-of the (50\%)were watching 3-5 serials per average day. The respondents were asked about the number of serials they watch every day to know about their serial viewing habits. The respondents were divided into four age groups. Analyzing the responses based on the age of the respondents, it was found that a higher proportion (30.7\%) respondents of the 30-39 age group, followed by $28.7 \%$ from the years of 18-29 age group and those in the age group of $42-49$ years(26.2\% ). A lower proportion(14.4\%) of old aged respondents (50and above years). Of these 20 respondents watching 1-2 serials, 13 respondents watching 3-5 serials and only 2 respondents watching 6-8 serials an average day.

Table 4.How many serials watched on an average day with the respondent's income levels?

\begin{tabular}{|l|c|c|c|c|c|}
\hline Annual income is Rs. & $1-2$ serials & $3-5$ serials & $6-8$ serials & 9 above serials & Total \\
\hline Below 50,000 & 42 & 51 & 14 & 1 & 108 \\
\hline 1 Lakh & 31 & 49 & 9 & 3 & 90 \\
\hline 2 Lakh & 13 & 15 & 2 & - & 32 \\
\hline 3 Lakh & 1 & 2 & 2 & - & 5 \\
\hline 4 Lakh & 2 & 2 & - & - & 4 \\
\hline 5 Lakh above & 1 & 3 & 29 & 3 & 5 \\
\hline Total & 90 & 122 & & & 244 \\
\hline
\end{tabular}

Around $44.3 \%$ of respondents are coming under the income group of below Rs.50,000. Followed by $36.9 \%$ of respondents' annual income group is Rs.1lakh and 13.2\% of respondents earned Rs.2 lakh. Among the 244 respondents, the highest number of 51 respondents watched 3-5 serials and their income by below Rs.50, 000 per annum. Followed by 49 respondents from Rs.1lakh income. Among 244 respondents 90 were watched 1-2 serials per day. Among 90 respondents 42 were below Rs.50, 000 and 31 respondents were Rs.1 lakh per year. Of three respondents who watch 9 serials a day, one gets Rs50, 000, the other one Rs.1 lakh, and another one gets 2 lakhs per year. Out of 244 respondents, 29 were watching 6-8 serials per day. Of these 14 respondents gets below 50 thousand rupees income per year and 9 respondents get 1 lakh rupees income per year.

Table 5. How many serials watched on an average day with the respondent's education levels?

\begin{tabular}{|l|c|c|c|c|c|}
\hline Level of education & $1-2$ serials & $3-5$ serials & $6-8$ serials & 9 above serials & Total \\
\hline Illiterate's & 14 & 23 & 7 & 2 & 46 \\
\hline Primary & 33 & 37 & 8 & - & 78 \\
\hline Secondary & 17 & 30 & 11 & - & 58 \\
\hline Technical & 13 & 10 & - & - & 23 \\
\hline Intermediate & 11 & 20 & 2 & - & 33 \\
\hline UG/PG & 2 & 2 & 1 & 1 & 6 \\
\hline Total & 90 & 122 & 29 & 3 & 244 \\
\hline
\end{tabular}

When the respondents asked about their education qualification. It was found that 78 out of 244 respondents were belonging to primary education, 58 respondents were secondary education, 46 of them were illiterates and 33 respondents were intermediate. Interestingly 6 out of 244 respondents came undergraduate and postgraduate degrees in different subjects.

Table 6. How many serials watched on an average day with respondents' occupations?

\begin{tabular}{|l|c|c|c|c|c|}
\hline Occupations & $1-2$ serials & $3-5$ serials & $6-8$ serials & 9 aboveserials & Total \\
\hline Student & 9 & 14 & 4 & - & 27 \\
\hline Homemaker & 16 & 37 & 10 & 3 & 66 \\
\hline
\end{tabular}


IRA-International Journal of Management \& Social Sciences

\begin{tabular}{|l|c|c|c|c|c|}
\hline Cultivation & 3 & 1 & 1 & - & 5 \\
\hline Labor & 10 & 19 & 4 & - & 33 \\
\hline Self Employed & 18 & 17 & 5 & - & 40 \\
\hline $\begin{array}{l}\text { Government } \\
\text { employee }\end{array}$ & 1 & 4 & 2 & - & 7 \\
\hline Private Employee & 13 & 15 & 1 & - & 29 \\
\hline Business & 5 & 3 & 1 & - & 9 \\
\hline Professionals & 1 & - & 1 & - & 2 \\
\hline Pensioner & 12 & 10 & - & - & 4 \\
\hline Artisans & 2 & 2 & 29 & 3 & 244 \\
\hline Total & 90 & 122 & & & \\
\hline
\end{tabular}

Out of 244 respondents, 122 were watched 3-5 serials per day and among 122 respondents 37 respondents were primary education, 30 were secondary and 23 respondents were illiterate. Out of 244 respondents, 90 were watched 1-2 serials per day. Among 90 respondents 33 were primary and 17 were secondary education. Of three respondents who watch 9 serials a day one is have UG/PG, another two were illiterates (Table -5).

Out of 244 respondents, 66 were homemakers (27\%), followed by self-employees 40 (16.4\%), labor 33(13.5\%). Private employees 29(11.9\%)students, 27(11.1\%)and pensioners 23(9.4\%).

Out of 244 respondents, 50\%(122) were watched 3-5 serials per day and 36.9\%(90) were watched 1-2 serials per day. Only 3respondents from homemakers watched 9 above serials and 10 respondents were watched 6-8 serials per day.

Table 7. How many channels watched an average day with Gender?

\begin{tabular}{|l|c|c|c|c|c|c|}
\hline $\begin{array}{c}\text { No. of } \\
\text { Channels }\end{array}$ & Male & $\%$ & Female & $\%$ & Total & $\%$ \\
\hline Only one & 15 & 14.6 & 13 & 9.2 & 28 & 11.5 \\
\hline $2-3$ & 72 & 69.9 & 85 & 60.3 & 157 & 64.3 \\
\hline $4-5$ & 13 & 12.6 & 36 & 25.6 & 49 & 20.1 \\
\hline More than 6 & 3 & 2.9 & 7 & 4.9 & 10 & 4.1 \\
\hline Total & 103 & 100.0 & 141 & 100.0 & 244 & 100.0 \\
\hline
\end{tabular}

About $64.5 \%$ of the respondents watched 2-3 channels per average day. The remaining $20.1 \%$ of respondents watched 4-5 channels and $11.5 \%$ watched only one channel an average day. Only $4.1 \%$ of the respondents were watched more than 6 channels. Among the female respondents, 25.6\% were watched 4-5 channels per day, and among 103 male respondents, onlly $12.6 \%$ were watched 4-5 channels per day. Among 103 male respondents, only 15 only watched one channel for serials. Out of 141 women respondents, 85 watched 2-3 channels, 36 watched 4-5 channels. If 10 respondents watch more than 6 channels, 7 of them female respondents, and three were male respondents.

Table 8 which channels you are watched for serials (Give Rank Order?)

\begin{tabular}{|c|c|c|c|c|c|c|c|c|c|c|c|}
\hline \multirow{2}{*}{\multicolumn{2}{|c|}{ Name of the Channel }} & \multicolumn{9}{|c|}{ Rank Order } & \multirow{2}{*}{$\begin{array}{c}\begin{array}{c}\text { Total } \\
(\mathrm{N}=316)\end{array} \\
\mathrm{N}\end{array}$} \\
\hline & & 1 & 2 & 3 & 4 & 5 & 6 & 7 & 8 & 9 & \\
\hline \multirow{2}{*}{ ETV } & $\mathrm{N}$ & 70 & 94 & 33 & 9 & 2 & - & - & - & - & 208 \\
\hline & $\%$ & 33.6 & 45.2 & 15.9 & 4.3 & 0.9 & - & - & - & - & 100.0 \\
\hline \multirow{2}{*}{ GEMINI TV } & $\mathrm{N}$ & 26 & 40 & 35 & 14 & 2 & - & 2 & - & 1 & 120 \\
\hline & $\%$ & 21.7 & 33.3 & 29.2 & 11.7 & 1.7 & - & 1.7 & - & 0.8 & 100.0 \\
\hline \multirow{2}{*}{ STAR Maa } & $\mathrm{N}$ & 41 & 40 & 46 & 20 & 3 & - & 1 & 1 & - & 152 \\
\hline & $\%$ & 26.9 & 26.3 & 30.3 & 13.2 & 1.9 & - & 0.7 & 0.7 & - & 100.0 \\
\hline \multirow{2}{*}{ ZEE Telugu } & $\mathrm{N}$ & 99 & 43 & 28 & 19 & - & 1 & - & - & - & 190 \\
\hline & $\%$ & 52.1 & 22.6 & 14.7 & 10.0 & - & 0.5 & - & - & - & 100.0 \\
\hline DD Saptagiri & $\mathrm{N}$ & 3 & 1 & 4 & - & 6 & 8 & 1 & 1 & - & 24 \\
\hline
\end{tabular}


IRA-International Journal of Management \& Social Sciences

\begin{tabular}{ll|l|l|l|l|l|l|l|l|l|c}
\hline & $\%$ & 12.5 & 4.2 & 16.7 & - & 25.0 & 33.3 & 4.2 & 4.2 & - & 100.0 \\
\hline
\end{tabular}
The respondents were asked about their ranking on TV channels. Interestingly 52.1\% of respondents given to
the first rank to ZEE Telugu serials followed by $45.2 \%$ of respondents ranked $2^{\text {nd }}$ to ETV. 30.3\% (46)
respondents to STAR Maa and 29.2\% of respondents given to $3^{\text {rd }}$ rank to Gemini.

Table 9 Which Telugu TV channels telecast more and more unethical serials by Gender?

\begin{tabular}{|c|c|c|c|c|c|c|c|c|c|}
\hline $\begin{array}{l}\text { Name of } \\
\text { the TV } \\
\text { channel }\end{array}$ & Gender & $\begin{array}{c}1 \\
\text { Agree }(\%)\end{array}$ & 2 & 3 & 4 & 5 & 6 & $\begin{array}{c}7 \\
\text { Disagree }\end{array}$ & Total \\
\hline \multirow{2}{*}{ ETV } & Male & 77.5 & 3.75 & 1.25 & 2.6 & 8.7 & 3.75 & 2.6 & 80 \\
\hline & Female & 69.4 & 0.9 & 4.5 & 2.7 & 8.1 & 6.3 & 8.1 & 111 \\
\hline \multirow{2}{*}{$\begin{array}{c}\text { Gemini } \\
\text { TV }\end{array}$} & Male & 55.2 & - & 7.9 & 15.8 & 10.5 & 5.3 & 5.3 & 38 \\
\hline & Female & 47.7 & 4.5 & 4.5 & 14.9 & 7.5 & 7.5 & 13.4 & 67 \\
\hline \multirow{2}{*}{$\begin{array}{c}\text { STAR } \\
\text { Maa }\end{array}$} & Male & 51.5 & 5.7 & 11.4 & 14.3 & 5.7 & 5.7 & 5.7 & 35 \\
\hline & Female & 54.4 & 11.8 & 11.8 & 4.4 & 4.4 & 5.9 & 7.3 & 68 \\
\hline \multirow{2}{*}{$\begin{array}{c}\text { Zee } \\
\text { Telugu }\end{array}$} & Male & 65.2 & 6.5 & 6.5 & 6.5 & 6.5 & 4.4 & 4.4 & 46 \\
\hline & Female & 61.9 & 9.5 & 7.9 & 4.8 & 1.6 & 4.8 & 9.5 & 63 \\
\hline \multirow{2}{*}{$\begin{array}{c}\text { DD } \\
\text { Saptagiri }\end{array}$} & Male & 13.6 & - & - & - & - & 4.6 & 81.8 & 22 \\
\hline & Female & 6.25 & - & - & 3.1 & - & 9.4 & 81.3 & 32 \\
\hline
\end{tabular}

The respondents were asked about their opinion on which Telugu TV channels telecast more and more unethical serials? $77.5 \%$ male and $69.4 \%$ female respondents agree that ETV serials are more unethical followed by ZEE Telugu (65.2\% male, $61.9 \%$ female), STAR MAA (51.4\% male, $54.4 \%$ female)and Gemini (55.3\% male, $47.7 \%$ female). The audience is ( $81.8 \%$ male, $81.3 \%$ female) opinionated, that there are no immoral serials on DD Saptagiri.

\section{Opinions and views}

Table 10 Respondents agreement on TV serials

Do you think the effect of TV serials to be negative on the viewers' life?

\begin{tabular}{|} 
Do you think the effect of TV serials to be negative on the viewers' life? \\
\hline Gender & SA & A & Neu. & D A & SD & Total \\
\hline Male & $98(69.5)$ & $18(12.8)$ & $15(10.6)$ & $10(7.1)$ & - & $141(100.0)$ \\
\hline Female & $67(45.9)$ & $46(31.5)$ & $18(12.3)$ & $15(10.3)$ & - & $146(100.0)$ \\
\hline Are serials storylines closer to real life? \\
\hline Male & $49(34.3)$ & $52(36.3)$ & $17(11.9)$ & $22(15.4)$ & $3(2.1)$ & $143(100.0)$ \\
\hline Female & $41(28.9)$ & $58(40.8)$ & $20(14.1)$ & $18(12.7)$ & $5(3.5)$ & $142(100.0)$ \\
\hline Is there bad stuff dominating in Telugu serials? \\
\hline Male & $76(53.9)$ & $38(26.9)$ & $22(15.6)$ & $4(2.8)$ & $1(0.8)$ & $141(100.0)$ \\
\hline Female & $60(42.5)$ & $47(33.3)$ & $17(12.1)$ & $17(12.1)$ & - & $141(100.0)$ \\
\hline
\end{tabular}

Note: $\mathrm{SA}=$ Strong Agree, $\mathrm{A}=$ Agree to some extent, Neu. =Neutral=Dis Agree, $\mathrm{SD}=\mathrm{Strongly}$ Disagree

The respondents were asked to give their opinions and views on three different questions. Information about the negative impact of serials on viewers was gathered based on a Likert scale format rather than usual qualitative based questions, a brief descriptive statistics are provided in table 10 for those items with similar Likert scale description. The percentage of 5point Likert scale scoring of each item is provided and with self-explanation. The respondents were asked about the negative impact of serials on the viewer's life. $69.5 \%$ of male respondents and $45.9 \%$ female respondents were strongly agreeing. The researcher asked another question: Are serials storylines closer to real life? Only $34.3 \%$ male and $28.9 \%$ female respondents agreeing with the above question. The respondents were asked about the question-are their bad stuff is dominating in Telugu serials? $53.9 \%$ male and $42.5 \%$ female respondents were strongly agreed with the above statement.

\section{Focus- group discussion}

The researchers conducted a focus group discussion held with a group of 9 Participants (P)in the research area of Amravati brought out significant revelations of the reception of Telugu drama serials telecasted by TV channels. Extract of notes from the focus -group discussion.

Researchers: Do you feel these Telugu TV serials un-ethical? 
$\mathbf{P}$ (A): It is common for Telugu serials to have three or four weddings of heroin. This is a bad sign for society. For example, in the Abishekam serial airing on ETV, heroine Shirisha is married four times. A 20 years girl maintains a den with rowdies for kidnaps, rapes, and threats. She spent lakhs of rupees for this purpose.

P (B): Forgetting the past (Gemini airing serial Bandham), plastic surgery (ETV airing serial ManasuMamatha), these two things are very common in Telugu serials.

It is common for serial producers and directors to see that the character has gone into a coma when they want to introduce a new storyline in a new location.

For example, the hero character Vamsi of the Zee Channel serial Matemanthram.

$\mathbf{P}(\mathbf{C})$ : Using film story sequences as it is. The serial of Abhishekam has resembled the movie Balaramakrishnulu. It is sad to see serials in the names of the most recent hit movies, It's sad that the new names for serials. Recent popular movie titles such as Attarintiki Daredi and Seethamma Vakitlo Sirimalle Chettu.

P (D): Lady villain's character exhibits violence throughout the years. Viewers cannot tolerate this type of violence. Only the least favored. Year after year, the view of torture, anarchy, conspiracy, and intrigue is the view of the audience, that is, the culprit is expected to be punished by law. But the character ends up killing himself for the serial ending. Generally, good people swear to themselves that they should not fall into the hands of evil.E.g., AnthahPuram, Chandramukhi, Agnisakshi serials.

P (E): Others have been illegally exploiting their property and enjoying it. The heirs conspire to brutally block anyone who comes to us with that ash. If people fight for years to win their property. When the villain wants to be punished by the law, the villain, who considers the defeat a shame, punishes himself. It is sad to show villains that the righteous and the honest have sacrificed their souls not to die at the hands of the wicked. For example TV serials Anthahpuram, Chandramukhi.

P (F): Gaining wealth in illegal ways and enjoying them, serial directors show up as great things. It is very sad; we can see this in these serials. Ex: Aadade aadharam (ETV), Agni Sakshi (STAR maa).Some daily serials have been around for years, but the stories have changed. The name stays the same. The story of the beginning is not going to be remembered. Ex: Manasu Mamata (ETV)

$\mathbf{P}(\mathbf{G})$ : The villains are hurting themselves. Some heroines endure them without protesting.

Researcher: Do directors show up in their serials as a means of encouraging those with a demonic nature?

$\mathbf{P}(\mathbf{H})$ : According to the horoscope of the heroine's character, her horoscope shows that she is very lucky. But she has been struggling for years. Director knows when she's going to be lucky, but the audience doesn't know. Ex: Nalugu stambaalaata (ETV serial).

P (I): Lady Villains costume languages and gestures are very ugly. When they appear, the audience feels as if the TV has risen from the front.

\section{Findings and Discussion}

R.O. 1. To identify and analyze the demographic profiles of TV viewers in Andhra Pradesh.

The study sample shows that $13.5 \%$ and $2.12 \%$ of women respondents were watching $6-8$ serials and 9 above serials respectively. It could be noted that out of the total 244 respondents half-of the $(50 \%)$ were watching 3-5 serials per average day. Around $44.3 \%$ of respondents are coming under the income group of below Rs.50,000.When the respondents asked about their education qualification. It was found that 78 out of 244 respondents were belonging to primary education.

R.O.2. To examine the viewing habits of viewers.

Half of (122) were watched 3-5 serials per day. Out of 244 respondents, 66 were homemakers $(27 \%)$, followed by self-employees $40(16.4 \%)$. About $64.5 \%$ of the respondents watched 2-3 channels per average day.

R.O.3.To find out the viewer's priority on serials and channels.

The respondents were asked about their ranking on TV channels. Interestingly $52.1 \%$ of respondents given to the first rank to ZEE Telugu serials followed by $45.2 \%$ of respondents ranked $2^{\text {nd }}$ to ETV. $30.3 \%$ (46) respondents to STAR Maa and $29.2 \%$ of respondents given to $3^{\text {rd }}$ rank to Gemini. 
R.O.4.To find out the perception of TV viewers on Telugu drama serials.

The highest agreement $77.5 \%$ male and $69.4 \%$ female respondents agree that ETV serials are more unethical followed by ZEE Telugu (65.2\% male, $61.9 \%$ female). The respondents were asked about the negative impact of serials on the viewer's life. $69.5 \%$ of male respondents and $45.9 \%$ female respondents were strongly agreeing. The researcher asked another question: Are serials storylines closer to real life? Only $34.3 \%$ male and $28.9 \%$ female respondents agreeing with the above question. The respondents were asked about the question-are their bad stuff is dominating in Telugu serials? $53.9 \%$ male and $42.5 \%$ female respondents were strongly agreed with the above statement.

Watching TV is about people from all walks of life and different age groups. That is, it can be awkward to show bad things for years together. Because it is true that some of the weak minds easily affected badly. But some would argue otherwise. It is said that the scene and the events that are shown in the serials are based on what is happening in the media and the film and the society which impact is high. The incident in the magazine is overshadowed by a reader reading it one day. Those who are uneducated will not read the incident. But if the movie is bad, a few minutes seen, then forgetting the audience. Serials are not so, and poisoning is common throughout the years.

In the film, the criminal and the culprits are punished by law. But the criminals in the serials will continue to escape punishment. For example, if a 10-year-old starts watching a serial, even if he turns 20, the bad character in the serial will continue to get worse. People devote only a small amount of time for watch papers and cinema. But serials are used yearly for the audience. So the effect of serials can be good or bad on the viewer.

Broadcast on TV should be entertaining to the viewer. But if entertainment becomes bizarre, there is a danger of clumsy thinking in the audience. This is not to say that all serials are the same. There are a few serials that make up the mind and people and make them feel good. This is because the dialogue between the characters and the choice of the cast for the serials is very real. Also, the serials have restored the role of the family system, customs, and social values. If there is any role goes to the wrong track it is better to do it and to repent. For example, the Koilamma serial, aired on Star Maa, has introduced a new version. Each episode features at least one of their songs, making them musical. In these TV serials, however, the movie song is being used consistently

\section{Theoretical framework implications}

The cultivation theory of media developed by George Gerbner is adaptable for the present study. Cultivation theory, in its most basic form, suggests that television is responsible for or 'cultivating' viewer's perceptions of individuals. These individuals can be heavy viewers or light viewers who are exposed to television for a few hours in the day or week to seek entertainment. Gerbner has argued that the mass media cultivates attitudes and values among viewers and brings about effects that can be small, gradual, and indirectly set cumulative and significant.

\section{Conclusion}

Unfortunately, the value of women gradually deteriorated because of daily serials. Women became a symbol of cruelty rather than chastity. The research reveals that viewers are addicted to viewing themselves while admitting that the worst of TV serials are broadcast. Telugu serials should not be immoral if they are to guide future generations. Channel ownership, serial managers, must commit to values. The government should employ a regulatory mechanism to prevent that.

\section{References}

[1]. Ahmed A. \& Khalid M. (2012). Construction of contemporary women in soap operas. Commentaries Global Media Journal, 3(4).

[2]. Devadas M. B. \& Ravi B. K. (2013). Cultural impact of Television on urban youth - An Empirical study, International Journal of Humanities and Social Science Invention, 2(8), 43-52.

[3]. Dharba V. (2012). Women's representation in Indian Television serials (Ph.D.Thesis).

[4]. Monterio, Anjali (1998). Official Television and unofficial fabrications of the self; the spectator as subject, in Ashis Nandy (ed.) The secret politics of our desires, Delhi.

[5]. Nagulapalli. A. \& Shaw P. (2013, July 19). Telugu primetime violence abounds, The Hoot.

[6]. Narayanan A. (1987). The impact of TV on viewers. Bombay: Soumya Publications.

[7]. Pogalendhi R. (2015). A study on a Television programs popularity among Chennai urban women, IOSR Journal of Humanities and Social Science, 20(2), 37-43.

[8]. Ponsindhu, Nirmala S. (2014). Role of MSME in women entrepreneurial development, International Journal of Research and Development - A Management Review. 2(4), 10-14. 
[9]. Shoma.M (2009). Primetime soap-opera on Indian Television. Routledge India.

[10].Shruti I.L. (2014). Empowering women in Panchayathi Raj institutions: Role of Media, Journal Media, and social development, 2(1).

[11].Vandana (2011). Impact of Television on Rural women; A study of Mirzapur village, International referred research journal,2,17-18. 